\title{
DisSOLVED ORGanic MatTER IN THE OCEAN: COMMENTS ON A CONTROVERSY
}

\author{
These elevated concentrations, as yet unconfirmed, \\ have been accepted as gospel by some, as heresy by others.
}

\author{
By P. M. Williams ${ }^{1}$ and E. R. M. Druffel ${ }^{2}$ \\ Institute of Marine Resources A-018. Scripps Institution of Oceanography, UCSD, La Jolla, California 92093, U.S. A \\ 'Department of Chemistry, Woods Hole Oceanographic Institution, Woods Hole, Massachusetts 02543, U.S.A.
}

Ifthese

recent $D O C$

and DON

results are

correct, there

is a lot of

explaining to

do concerning

the source of

the DOM, its

relative stability

to chemical and

microbial

oxidation, and

its molecular

composition. ecent measurements of dissolved (including colloidal) organic carbon (DOC) and nitrogen (DON) concentrations in the northwestern Pacific (Sugimura and Suzuki, 1988; Suzuki et al., 1985 ) are 50 to $400 \%$ higher than previous results found for oceanic surface and deep waters (Figures 1,2 ). These elevated concentrations, as yet unconfirmed, have been accepted as gospel by some, as heresy by others, with the skeptics somewhere in between.

Briefly, Sugimura and Suzuki (1988) and Suzuki et al. (1985) inject $200 \mu \mathrm{l}$ of filtered, acidified seawater onto a $3 \% \mathrm{Pt}$ on $\mathrm{Al}_{2} \mathrm{O}_{3}$ catalyst at $680^{\circ} \mathrm{C}$ and measure the resultant $\mathrm{CO}_{2}$ (from DOC) by infra-red absorption or the resultant NO (from DON) by oxidation to $\mathrm{NO}_{2}^{-}$with subsequent spectrophotometric determination. Their DOC values (180-490 $\mu \mathrm{M}$ in the upper $300 \mathrm{~m} ; 35$ to $85 \mu \mathrm{M}$ from 400 to $4100 \mathrm{~m}$ ) and DON values (30 to 45 $\mu \mathrm{M}$ in the upper $300 \mathrm{~m} ; 4$ to $15 \mu \mathrm{M}$ from 400 to $4100 \mathrm{~m}$ ) display oceanographic consistency: DOC and DON are inversely correlated with the apparent oxygen utilization (AOU) (Figure 2), where there are near uniform values of DON plus inorganic nitrogen $\left(\mathrm{NO}_{3}^{-}+\mathrm{NO}_{3}^{-}+\mathrm{NH}_{3}\right)$ and of DOC plus the carbon equivalent of $\mathrm{AOU}$ from the surface to the deep sea. Profiles of DOC, DON, $\mathrm{AOU}$ and $\mathrm{NO}_{3}^{-}$with these same general shapes were previously postulated in order to explain the $\mathrm{N}$ (and $\mathrm{P}$ ) cycle(s) relative to AOU values (Miyaki et al., 1982; 1985).

Believers would welcome high DOC and/or DON values to explain such anomalies as unknown protonated compounds (e.g., organic acids) which could account for the discrepancy between potentiometric and manometric measurements of total $\mathrm{CO}$, in surface seawater (Bradshaw and Brewer, 1988); also it may explain the imbalance between reduced carbon exported out of the euphotic zone (as measured by sediment traps) and the higher amounts expected from in situ production inferred from seasonal oxygen signals. The skeptics should be concerned because potentially significant increases in trace metal complexation could result from elevated dissolved organic matter (DOM) contents, and modification of global dissolved oxygen budgets vis-à-vis mineralization of this "excess" DOC and DON could occur in surface waters. The heretics simply do not believe that previous oxidation techniques have missed such a large fraction of the DOM and they are concerned because, at present, there is no evidence for the requisite dissolved organic phosphorus (DOP) (Suzuki, personal communication) or an equivalent $\mathrm{PO}_{4}^{3-}$ ) in surface waters as would be expected from Redfield C:N:P restraints.

If these recent DOC and DON results are correct, and for the purpose of this essay we will assume this is the case, there is a lot of explaining to do concerning the source of the DOM, its relative stability to chemical and microbial oxidation, and its molecular composition. These are not new queries, but they now assume a vital importance in oceanic carbon and nitrogen budgets and cycling, and in effect have stimulated a reawakening of an often dreary litany of the previously accepted, monotonic distributions of DOC and DON.

Chemical and Biochemical Stability of DOC

Some of the facts known about the stability of DOC are:

(1) DOC concentrations measured by different wet combustion techniques, for example, peroxydisulfuric acid, chromic acid, or short wavelength ultraviolet radiation (Armstrong et al., 1966: Menzel and Vaccaro, 1964; Duursma, 1961) are comparable in both surface and deep waters and show little or no changes below the upper $300-500 \mathrm{~m}$, nor do they correlate well with or reflect other oceanographic features or biological processes such as the oxygen minimum, surface primary productivity, and discrete water parcels (Williams et al., 1980; Menzel and Ryther, 1968; Gershey et al., 1979; Ogura, 1970; Holm-Hansen et al., 1966; Duursma, 1961)(see Figure 1). The same holds true for elevated DOC values measured by various high temperature catalytic combustion techniques (e.g., Gershey et al., 1979; Sharp, 1973; Gordon and Sutcliffe, 1973; 


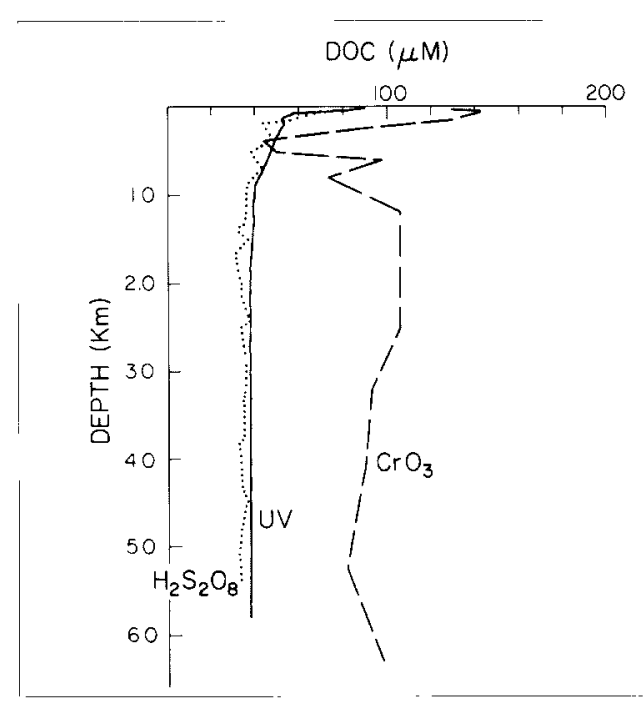

Figure 1. Profiles of DOC $(\mu M)$ in the North Pacific using different oxidative techniques: $U V$ radiation $(-, 31 \%, 159 \mathrm{~W}$. Williams and Druffel. 1987), peroxodisulfuric acid( , $31 \%, 168 \mathrm{~W}, L$. Gordon, personal communication, Geosecs Stn. $204)$, and chromic acid (- - - $32 \%, 142^{\circ} \mathrm{E}$. Plunkett and Rakestraw, 1955).

Skopintsev et al., 1966; Starikova and Yablokova, 1974) prior to the Suzuki and Sugimura (1988) results (Figure 2). An exception is the high DOC values found by Plunkett and Rakestraw (1955) using chromic acid oxidation of dried seawater from which most of the chloride ion had been removed by precipitation with thallium $\left(\mathrm{Tl}^{+}\right)$(Krogh, 1934)(Figure 1).

(2) Virtually all of the standard organic compounds added to seawater yield 70 to $100 \%$ recoveries upon wet or UV oxidation, including such "refractory" and/or high molecular weight substances as albumin, palmitic acid, pyridine, "humic" substances, and powdered chitin (an Nacetyl-D-glucosamine polymer). These recoveries temper speculations that during wet or UV oxidation of natural seawater concurrent oxidation of seawater halides reduces the oxidation potential thus leading to incomplete oxidation of the seawater DOC, or that the residual DOC measured by Sugimura and Suzuki (1988) is transparent to UV and hence is not oxidized;

(3) Surface water DOC, when allowed to incubate with the indigenous bacterial populations, is reduced to the concentration levels of DOC in deep waters (Barber, 1968), suggesting that this baseline fraction of the DOC measured by wet or UV oxidation is chemically reactive but is only very slowly utilized by bacteria;

(4) Recent determinations of the natural radiocarbon content of DOC in samples from the surface to $5720 \mathrm{~m}$ in the north central Pacific (Williams and Druffel, 1987) give mean apparent ages for UV-oxidizable DOC of 1300 yrs B.P. $\left(\Delta^{14} \mathrm{C}=\right.$ $150 \%)$ at the surface and 6000 years B.P. $\left(\Delta^{14} \mathrm{C}\right.$ $=-525 \%$ ) from 900 to $5720 \mathrm{~m}$. These values suggest that at least a portion of this DOC is recycled within the ocean on a $>10^{3}-10^{4}$ year time scale. These "old" ages are also reflected in humic, fulvic and hydrophilic acids isolated on XAD macroreticular resins from seawater samples collected at $180 \mathrm{~m}$, south of Hawaii (Druffel et al., in preparation; Thorn et al., 1987); and

(5) Copper complexation studies in the NE Pacific provide strong evidence for 2 types of organic copper complexing ligands: a weaker ligand whose concentrations show no apparent variation with depth $(0-1500 \mathrm{~m})$ and a stronglybound ligand that displays a subsurface maximum at the depth of the primary productivity maximum ( $50-75 \mathrm{~m}$ ) and is zero by $200 \mathrm{~m}$ (Coale and Bruland, 1988).

Thus it appears that the deep-sea DOC oxidized by wet or UV oxidation techniques is relatively inert to rapid biochemical utilization, is mixed conservatively within the deep-sea, and comprises about $50 \%$ of the wet or UV oxidizable DOC in the surface mixed layer, the remainder being more labile organic compounds of recent origin (Druffel et al., in preparation, Williams and Druffel, 1987).

Thus we are left with a paradox. What is the quality of the "extra" DOC (and DON) reported by Sugimura and Suzuki (1988) and Suzuki et al. (1985)? We know that this DOM does not oxidize readily, yet is utilized relatively rapidly by marine microbial community - at least judging from its covariance with $\mathrm{AOU}, \mathrm{NO}_{3}$ and dissolved $\mathrm{O}_{2}$, and the observation that it exhibits diurnal variations in productive waters (Y. Suzuki: personal communication).

Sugimura and Suzuki (1988) and Suzuki (personal communication) also found that the major portion of the DOC in surface water which is not oxidized by peroxydisulfuric acid is in the molecular weight range of 4000-22,000 Daltons and has a $\mathrm{C} / \mathrm{N}$ ratio of 5.6 to 6.8 by atoms (as compared to a normal $\mathrm{C} / \mathrm{N}$ ratio of 7-12 for wet or $\mathrm{UV}$ oxidizable DOC). This is approximately the same size range which accounts for an appreciable fraction of the missing DON (Suzuki et al., 1985). The implications are clear: the "extra", $N$ enriched, organic matter, derived from phytoplankton, is attractive to heterotrophic microorganisms, is probably polymeric, and has oxidation potentials and/or rates exceeding those of the standard compounds used in evaluating the efficiency of the wet, UV, and earlier high temperature oxidation techniques.

$\mathrm{O}$ ne way out of this dilemma is to postulate that the "extra" DOC is a highly cross-linked polymer derived from proteinaceous precursors (such as glycoproteins etc. in cell walls) by photochemical and/or microbial transformations in surface waters. Such a polymer would either be very slowly oxidized (molecular layer by molecular layer) by wet chemical or UV irradiation techniques, or its threshold oxidation potential would be too high for wet chemical techniques to effect any oxidation in the presence of 0.5 molar chloride ion. In fact, it is difficult to believe that this hypothetical substance would be truly soluble with a molecular weight of 4000 to 22,000
These elevated

concentrations,

as yet uncon-

firmed, have

been accepted

as gospel by

some, as heresy

by others, with

the skeptics

somewhere

in between. 


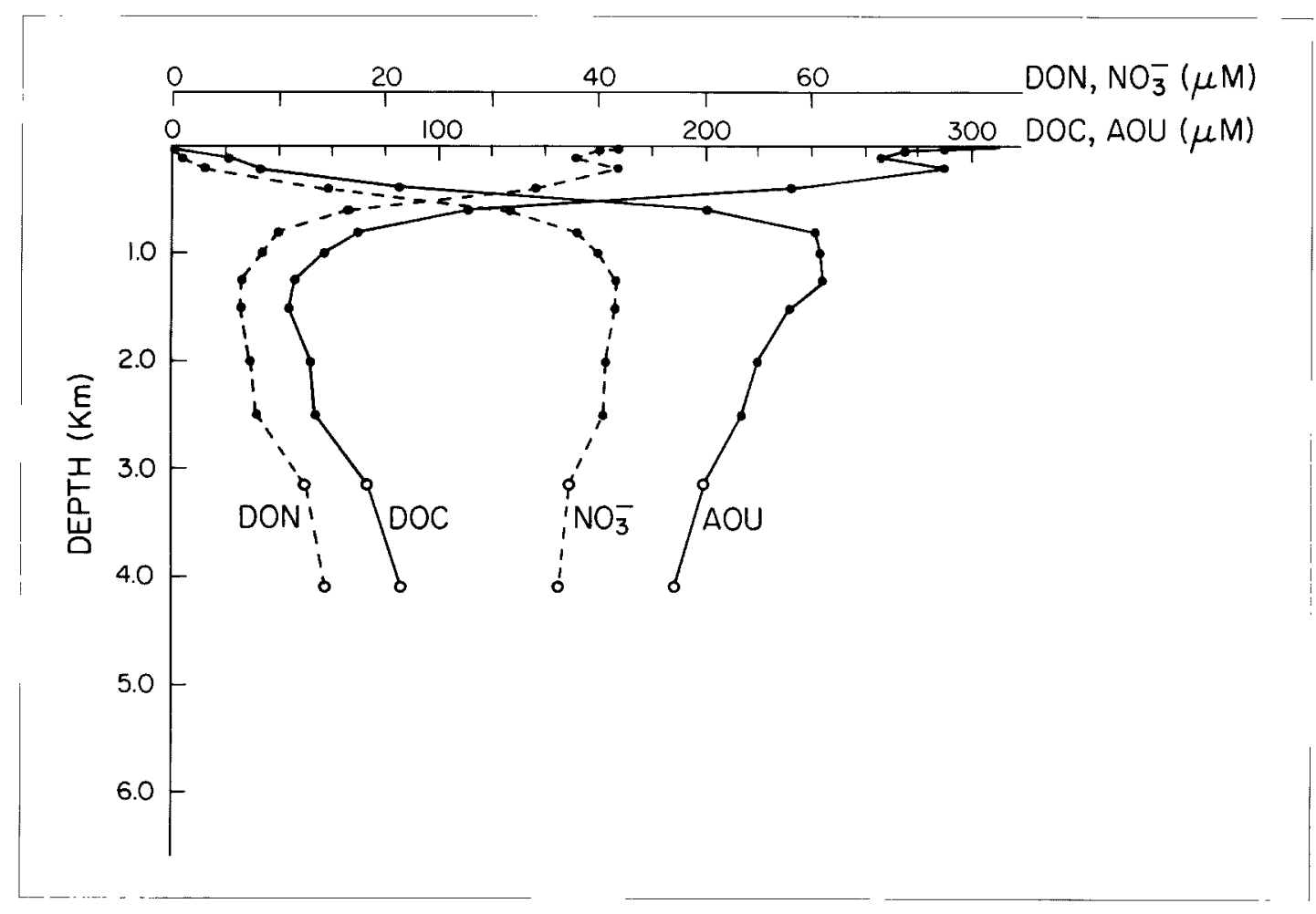

Figure 2. Profiles of DOC, DON, apparent oxygen utilization ( $A O U$ ), and $\mathrm{NO}_{3}$ as measured by Sugimura and Suzuki (1988) at $20^{\circ} \mathrm{N}, 137^{\circ} \mathrm{E}(-$.$) and 5^{\circ} \mathrm{N}, 135^{\circ} \mathrm{E}(-0-)$. The depth of the $\mathrm{O}_{2}$ minimum at $20^{\circ} \mathrm{N}, 137^{\circ} \mathrm{E}$ is between 800 and $1000 \mathrm{~m}$. Notice the similarity between this DOC profile and that of Plunkett and Rakestraw (Figure 1).

Daltons rather than being colloidal in nature.

The Molecular Composition Of DOC

There is not much known about the composition of DOC. The facts are that in surface waters about $15 \%$ of the "old" DOC (as measured by UV or wet oxidative techniques) can be identified as combined amino acids and carbohydrates, $1-2 \%$ as solvent-extractable lipids, and $20-50 \%$ as "humic substances" isolated on XAD-2, -8 , and -4 macroreticular polystytrene resins (Williams and Druffel, 1987; Thorn et al., 1987; Druffel et $a l$. , in preparation. In deeper waters, the combined amino acids and carbohydrates plus lipids account for 7 to $8 \%$ of the DOC and the "humic substances" $\geq 10 \%$. In addition, a number of trace organic compounds (urea, organometallics, Krebs cycle acids, etc.) have been identified, primarily in surface waters (Williams, 1986), and account for less than $1 \%$ of the DOC. The "new" Sugimura and Suzuki (1988) elevated DOC values would reduce these identifiable constituents by factors of 2 to 3 in surface and deep waters. Thus we are confronted with the challenge of identifying an additional 100 to $300 \mu \mathrm{M}$ of DOC and $20-40 \mu \mathrm{M}$ of DON in surface waters and 10 to $50 \mu \mathrm{M}$ DOC and 1 to $5 \mu \mathrm{MDON}$ below $300 \mathrm{~m}$-most of which must be resistant to chemical or UV oxidation, relatively labile to rapid bacterial utilization and degradation, and presumably (see below) of marine origin.

\section{The Source of DOC}

It has been assumed that the bulk of DOC (and DON) has its fundamental origin in surface ocean waters via such processes as phytoplankton excretion, lysis and solubilization of living and detrital particulate organic matter (microplankters, fecal material, extracellular exudates, etc.) and "sloppy feeding" at various trophic levels. On the other hand, it has been postulated that $50 \%$ or more of the DOC in the oceans arises from river inputs of soluble organic matter which is conserved rather than removed during estuarine flocculation and degradative processes (Mantoura and Woodward, 1983). Current analytical data. however, does not support a significant riverine contribution to oceanic DOM. First, lignin (uniquely identified by its oxidation products [Hedges and Ertel, 1982]), whose origin is restricted solely to terrestrial sources, occurs in rivers, coastal waters, and in sediments bordering continental runoff areas (e.g., Hedges and Mann, 1979; Ertel et al., 1986; Hedges et al., 1986). It is not found, however, in open ocean water at 5 and $150 \mathrm{~m}$ at two locations in the eastern tropical Pacific (Meyers-Schulte and Hedges, 1986). Second, the ${ }^{13} \mathrm{C} /{ }^{12} \mathrm{C} \quad \delta^{13} \mathrm{C}$ ) ratios of "old" open ocean DOC are -20 to $-22 \%$ (Williams and Druffel, 1987; Meyers-Schulte and Hedges, 1986) while riverine (Amazon) DOC and POC have values of -28 (Williams and Gordon, 1970) and -26 to $-32 \%$ (Hedges et al., 1986), respectively. Third, diurnal variations in the low molecular weight fraction of the DOC (Suzuki, personal communication) demand a phytoplankton source, and thus limit the contribution of riverine DOC, at least in surface waters. These facts suggest that riverine contributions are less than $10 \%$ of the total marine DOC pool. Additional analyses of lignin oxidation products in surface and deep waters of the Pacific and Atlantic (whose river 
sources are much higher than for the Pacific) should more precisely define the magnitude of terrestrial input to the dissolved organic matter pool.

What does all of this mean to the oceanographic community and where do we go from here? Confirmation of the elevated DOC and DON values of Sugimura and Suzuki (1988) and Suzuki et al. (1985) is the first mandate. This includes confirmation using other methods, e.g.. closedtube combustion of dried seawater samples. If these measurements reveal consistently higher DOC values, then a series of experiments must be run to determine the identity and source of this DOM and its resistivity to chemical and UV oxidation. Such experiments would include: exposing seawater solutions of proteinaceoustype compounds (including the indigenous microbial populations) to various periods of incubation with natural UV- $\beta$ radiation and measuring the DOC by both UV and Suzuki methodologies; adding ${ }^{14} \mathrm{C}$ and ${ }^{3} \mathrm{H}$-labelled bacteria and/or phytoplankters to seawater and determining whether or not the label is incorporated into UV-resistant fractions of the resultant, size-fractionated organics, both soluble and colloidal: and measuring the natural $\Delta^{14} \mathrm{C}$ and $\delta^{13} \mathrm{C}$ values in the additional DOC to estimate its source, its apparent "age" with respect to production and the rate at which it is entering the deep sea.

It also means that the role of DOM in the biogeochemical cycles of organic carbon, organic nitrogen, $\mathrm{O}_{2}$, inorganic $\mathrm{N}$ and $\mathrm{P}$ nutrients, $\mathrm{CO}$, and trace metals will have to be re-evaluated. In addition, a closer evaluation of the role of this new DOM to phytoplanktonic growth must be done. REFERENCES

Armstrong. F. A. J., P. M. Williams, and J. D. H. Strickland, 1966. Photo-oxidation of organic matter in seawater by ultra-violet radiation, analytical and other applications. Nature, 211, 481- 483.

Barber, R. T., 1968. Dissolved organic carbon from deep waters resists microbial oxidation. Nature. 220 . 274-275.

Bradshaw. A. L., and P. G. Brewer, 1988. High precision measurements of alkalinity and total carbon dioxide in seawater by potentiometric titration. 1 . Presence of unknown protolyte(s)? Mar. Chem., 23, 69-86.

Coale, K. H., and K. W. Bruland, 1988. Copper complexation in the northeast Pacific. Limnol. Oceanogr.. in press.

Duursma, E. K., 1961. Dissolved organic carbon, nitrogen and phosphorus in the sea. Neth. J. Sea. Res. 1, 1-148.

Ertel, J. R., J. I. Hedges, A. H. Devol, J. E. Richey, and M. G. Ribeiro, 1986. Dissolved humic substances of the Amazon River system. Limnol. Oceanogr.. 31. 739-754.

Gershey, R. M., M.D. Mackinnon.P.J. LeB. Williams, and R. M. Moore, 1979. Comparison of three oxidation methods used for the analysis of dissolved organic carbon in seawater. Mar. Chem., 7, 289-306.

Gordon, D. C.. Jr., and W. H. Sutcliffe, Jr., 1973. A new dry combustion method for the simultaneous determination of total organic carbon and nitrogen in seawater. Mar. Chem., 1, 231-244.

Hedges. J. I., and D. C. Mann, 1979. The characterization of plant tissues by their lignin oxidation products. Geochim. Cosmochim. Acta, 43, 1809-1818. , and J. R. Ertel, 1982. Characterization of lignin by gas capillary chromatography of cupric oxide oxidation products. Anal. Chem., 54, 174-178. W. A. Clark, P. D. Quay, J. E. Richey, A. H. Devol, and U. deM. Santos, 1986. Compositions and fluxes of particulate organic material in the Amazon River. Limnol. Oceanogr., 31, 717-738.

Holm-Hansen, O.. P. M. Williams, and J. D. H. Strickland, 1966. A detailed analysis of biologically important substances in a profile off southern California. Limnol. Oceanogr., 11. 548-558.

Krogh, A., 1934. Conditions of life at great depths in the ocean. Ecol. Monogr., 4, 430-439.

Mantoura, R. F. C., and E. M. S. Woodward, 1983. Conservative behavior of riverine dissolved organic carbon in the Severn Estuary: chemical and geochemical implications. Geochim. Cosmochim. Acta, 47 , 1293-1309.

Menzel, D. W., and R. F. Vaccaro, 1964. The measurement of dissolved organic and particulate carbon in seawater. Limnol. Oceanogr.. 9, 138-142. , and J. Ryther, 1968. Organic carbon and the oxygen minimum in the South Atlantic Ocean. DeepSeaRes., 15, 327-337.

Meyers-Schulte, K. J., and J. I. Hedges, 1986. Molecular evidence for a terrestrial component of organic matter dissolved in ocean water. Nature, 321, 61-63. Miyaki, Y., T. Sagi, and K. Saruhashi, 1982. The biogeochemical cycle of nitrogen and phosphorus in the ocean. Science Report. Geochemistry Research Association, Suginami, Tokyo, 1-22.

. K. Saruhashi, T. Kanazawa. and T. Sagi, 1985. On the dissolved carbon in seawater. Bull. Soc. Seaw'ater Sci. Japan, 38, 353-367 (in Japanese).

Ogura. N., 1970. The relation between dissolved organic carbon and apparent oxygen utilization in the western North Pacific. Deep-Sea Res., 17, 221-231. Plunkett, M. A., and N. W. Rakestraw, 1955. Dissolved organic matter in the sea. Deep-Sea Res., suppl. to Vol. 3, 12-14.

Sharp, J. H.. 1973. Total organic carbon in seawatercomparison of measurements using persulphate oxidation and high temperature combustion. Mar. Chem., l, 211-229.

Skopintsev, B. A., S. N. Timofeyeva, and O. A. Vershinina, 1966. Organic carbon in the near-equatorial and southern Atlantic and in the Mediterranean. Oceanology, 6, 201-210.

Starikova. N. D., and O. G. Yablokova. 1974. Organic matter in northwestern Pacific Ocean water (Tsugaru Strait-Wake Island section). Oceanology, 14, 833837.

Sugimura, Y., and Y. Suzuki, 1988. A high temperature catalytic oxidation method of non-volatile dissolved organic carbon in seawater by direct injection of liquid samples. Mar. Chem., in press.

Suzuki, Y.. T. Sugimura, and T. Itoh, 1985. A catalytic oxidation method for the determination of total nitrogen dissolved in seawater. Mar. Chem., 16, 83-97.

Thorn, K. A., G. R. Aiken, R. L. Malcolm, and D. M. McKnight, 1987. Characterization of the fulvic acid and hydrophilic acid fractions of DOC using C-13 and H-1 NMR spectrometry: a comparison of marine and freshwater samples. EOS, 68, 1730.

Williams, P. M., and L. I. Gordon. 1970. Carbon13: carbon-12 ratios in dissolved and particulate organic matter in the sea. Deep-Sea Res., 17, 19-27.

. A. F. Carlucci, and R. Olson, 1980. A deep profile of some biologically important properties in the central North Pacific gyre. Oceanologica Acta, 3, 471476.

, 1986. Chemistry of the dissolved and particulate phases in the water column. Plankton Dynamics of the Southern California Bight, R. W. Eppley, Ed.. Springer-Verlag, New York, 53-82.

and E. R. M. Druffel, 1987. Radiocarbon in dissolved organic matter in the central North Pacific Ocean. Nature, 330, 246-248.
Confirmation

of the elevated

DOC and DON

values of

Sugimura and

Suzuki (1988)

and Suzuki et al.

(1985) is the first

mandate. 